\title{
Kvaliteta usluga za beskućnike: prikaz trenutnog stanja i izazova u Hrvatskoj
}

\author{
LYNETTE ŠIKIĆ-MIĆANOVIĆ * \\ SUZANA SAKIĆ \\ STEPHANIE STELKO
}

Institut društvenih znanosti Ivo Pilar Zagreb, Hrvatska

\author{
Prethodno priopćenje \\ UDK: 364.273:364.48(497.5) \\ doi: $10.3935 /$ rsp.v27i3.1693 \\ Primljeno: siječanj 2020.
}

\begin{abstract}
Iako je beskućništvo složena tema koja je u posljednjih desetak godina pobudila interes hrvatske znanstvene zajednice, $u$ dosadašnjim radovima na tu temu nije se govorilo o kvaliteti socijalnih usluga namijenjenih osobama s iskustvom beskućništva. Upravo ta tema problematizirana je u ovom članku na temelju kvalitativnog istraživanja koje je obuhvatilo ključne sudionike u području pružanja usluga za beskućnike. Nakon uvodnog dijela i opisa metodologije, u članku je opisana pravna regulacija kvalitete usluga za beskućnike, ali i problemi na koje pružatelji usluga za beskućnike nailaze pri praktičnoj primjeni pravnih dokumenata. Nadalje, članak analizira: dostupnost usluga za beskućnike, načine njihovog financiranja, kvalitetu smještanih objekata, kvalitetu socijalnih usluga te kontrolu kvalitete. Svi ovi aspekti kvalitete usluga popraćeni su nizom primjera iz prakse, kao i nekim primjerima dobre prakse.
\end{abstract}

Ključne riječi: beskućnici, socijalne usluge, prihvatilišta, prenoćišta, regulacija, kvaliteta usluga.

\section{UVOD}

$\gg(. .$.$) te usluge moraju biti standardizira-$ ne i moraju sredstva biti podjednaka ovisno o broju ljudi i moraju, moraju, ako je propisano da se beskućniku nudi hrana, odjeća, obuća i to i onda se mora nuditi i aktivnost i socijalnog uključivanja, ne mogu oni očekivati u 6 mjeseci da će on otići«. (KI_01.)

Ovom je rečenicom voditelj jedne od organizacija koja pruža usluge beskućnicima sumirao neke od gorućih problema u sustavu socijalne skrbi u Hrvatskoj za jednu od najranjivijih društvenih skupina. Svrha ustanova koje pružaju smještaj beskućnici- ma nije njihova marginalizacija i uklanjanje s vidljivih prostora u gradovima, nego socijalna inkluzija korisnika što podrazumijeva visoku kvalitetu usluga, uključujući dostojanstven i jednak tretman. Međutim, pitanje je koliko je to moguće, s obzirom na nepostojanje nacionalne strategije o beskućništvu te nedostatak preventivnih mjera, o čemu izvještava i pučka pravobraniteljica u svom izvješću (2019.). Uz ovaj problem, Ured pučke pravobraniteljice identificirao je niz drugih problema, koji direktno ili indirektno utječu i na kvalitetu usluga za beskućnike, uključujući neusklađenost de-

* Lynette Šikić-Mićanović, Institut društvenih znanosti Ivo Pilar / Institute of Social Sciences Ivo Pilar, Marulićev trg 19, 10000 Zagreb, Hrvatska / Croatia, Lyn.Sikic-Micanovic@pilar.hr 
finicije beskućnika s ETHOS tipologijom, nemogućnost da beskućnici u prihvatilištima primaju zajamčenu minimalnu nakna$\mathrm{du}$, odnosno nedostatne iznose naknade za one koji ne koriste usluge prihvatilišta (2020.), nedostatak stambenih politika (2018.), nedovoljno podrške pri uključivanju na tržište rada (2018.) te boravak osoba s kompleksnim potrebama u prihvatilištima i prenoćištima (2016.).

Zaključak najnovije European Observatory on Homelessness (EOH) komparativne studije o beskućništvu ${ }^{1}$ je da postoji nedosljednost u području regulacija i upravljanja uslugama za beskućnike u većini EU zemalja, kao i razlike među različitim zemljama (Pleace, Baptista, Benjaminsen, i Busch-Geertsema, 2020.: 75). Autori navode da ideja toga što čini »dobru« uslugu nije univerzalna; neki se zalažu za model u kojem korisnici usluge imaju glavnu riječ, koproduktivni model koji uključuje ideje poput Housing first (stanovanje prvo), dok drugi smatraju da usluge trebaju biti direktivne, intervenirajući na promjenu ponašanja osoba u beskućništvu (2020.: 9). FEANTSA već godinama potiče raspravu o kvaliteti usluga za beskućnike (Allen, 2012.: 160), koristeći pri evaluaciji Donabedianov model koji u obzir uzima strukturu, proces $\mathrm{i}$ ishod pružene usluge. Wolf i Edgar objašnjavaju navedeni model (Donabedian, 1980.: 80, citirano u Wolf, Edgar 2007.: 24) na sljedeći način: »struktura« označava relativno stalne karakteristike pružatelja usluga, poput ljudskih, fizičkih i financijskih resursa kojima raspolažu. »Proces « se odnosi na »odnos između karakteristika pro- cesa skrbi, posljedica na zdravlje i dobrobit pojedinca i društva, sukladno vrijednosti koju pojedinac i društvo pridaju zdravlju i dobrobiti«. »Ishod « podrazumijeva vidljivu promjenu statusa korisnika u smislu smještaja, zdravlja i zaposlenosti koja se može pripisati pruženim uslugama (ibid). Uz kvalitetu usluga, EOH je zanimalo i je li njihovo pružanje omogućeno, olakšano ili otežano sustavom propisanih pravila i procedura.

Glavni cilj ovog istraživanja je istražiti kvalitetu usluga za beskućnike u Hrvatskoj. Istraživanje je inicijalni korak u razumijevanju trenutnog stanja standarda kvalitete i regulacije usluga u području beskućništva u Hrvatskoj. Veoma je važno istaknuti da bismo voljeli potaknuti raspravu na temu koja je marginalizirana i nije joj dana pažnja u akademskim krugovima te u području donošenja politika na nacionalnoj razini. Ova studija usmjerena je na uvide ključnih dionika i djelatnika koji su neposredno uključeni u rad s osobama u beskućništvu pa tako ovim člankom želimo dati glas pružateljima usluga i izazove s kojima se svakodnevno suočavaju u svome radu, učiniti vidljivima.

\section{METODOLOGIJA}

Ova kvalitativna analiza dio je veće studije o beskućništvu i putovima k socijalnoj inkluziji u Hrvatskoj ${ }^{2}$. Članak je prvenstveno inspiriran komparativnom studijom koju je hrvatski istraživački tim proveo za $E u$ ropean Observatory on Homelessness na temu kvalitete usluga za beskućnike u 2019. Ova studija istražuje standarde i sustave koji se koriste za strukturiranje, nadgledanje,

\footnotetext{
${ }^{1}$ Ova komparativna studija izvještava o stanju i regulaciji usluga za beskućnike u Europi. U studiji su sudjelovali stručnjaci iz 16 zemalja članica EU-a: Austrije, Hrvatske, Čške, Danske, Finske, Francuske, Njemačke, Mađarske, Irske, Italije, Nizozemske, Poljske, Portugala, Rumunjske i Slovenije.

2 Trogodišnji međunarodni projekt (No. IZHRZO_180631/1) Exploring Homelessness and Pathways to Social Inclusion: A Comparative Study of Contexts and Challenges in Swiss and Croatian Cities (CSRP) financiran je u okviru hrvatsko-švicarskog istraživačkog programa Hrvatske zaklade za znanost i Švicarske nacionalne zaklade za znanost putem sredstava švicarsko-hrvatskog programa suradnje. Provode ga timovi s Instituta društvenih znanosti Ivo Pilar te Institute for Social Planning, Organizational Change and Urban Development, University of Applied Sciences and Arts Northwestern Switzerland.
} 
ispitivanje i upravljanje kvalitetom usluga za beskućnike.

Metodom polustrukturiranog intervjua ispitana je kvaliteta pružanja usluga i uspostavljenost sustavnih pristupa i procedura koji osiguravaju njihovu kvalitetu. Rezultati predstavljeni u ovom radu kompilacija su podataka prikupljenih u oba spomenuta istraživanja. Interes je bio usmjeren na načine na koje se provode pravila i propisi o kvaliteti usluga, ali i na ključne aspekte kvalitete, kao što su oblik smještaja (prenoćište/prihvatilište), broj zaposlenih u odnosu na broj korisnika, broj korisnika koji dijele sobu, opremljenosti prostorija, odvojenih spavaonica i sanitarnih čvorova za muškarce i žene itd. Također je istražena i kvaliteta usluga s obzirom na podskupine unutar populacije beskućnika (npr. mladi, obitelji s djecom, migranti, osobe s višestruko složenim potrebama).

U uzorak su uključena 3 prenoćišta i 5 prihvatilišta za beskućnike i bio je izazov jasno razgraničiti ova dva tipa usluga, budući da mnoge usluge obuhvaćaju obje funkcije. ${ }^{3}$ Prenoćišta i prihvatilišta uključena u uzorak odabrana su na temelju svog zemljopisnog položaja (kako bi se dobio uzorak reprezentativan na nacionalnoj razini) i na temelju organizacija koje ih vode (kako bi bila zastupljena ona koja vode organizacije prisutne na međunarodnoj razini poput Crvenog križa i Caritasa, kao i ona koje vode organizacije koje djeluju nacionalno ili lokalno). Sudionici istraživanja bili su stručni djelatnici prihvatilišta i prenoćišta za beskućnike (voditelji, koordinatori, dežurni djelatnici u prihvatilištu/prenoćištu, socijalni radnici, psiholozi) i predstavnici Hrvatske mreže za beskućnike (radi sveobuhvatnog pristupa, budući da je 13 pri- hvatilišta/prenoćišta uključeno u Mrežu) te predstavnici Ministarstva za demografiju, obitelj, mlade i socijalnu politiku (kao tijela nadležnog za uređenje sustava socijalnih usluga).

Provedeno je 10 intervjua s 15 sudionika, budući da su u nekim slučajevima u intervjuu sudjelovale po 2 osobe (s obzirom na specifična znanja i uključenost u različite aspekte rada). Trajanje provedenih intervjua iznosilo je od 1 do 3 sata, a sva imena i druge identifikacijske oznake uklonjene su radi osiguranja anonimnosti sudionika. Istraživanje je odobreno od strane etičkog povjerenstva Instituta društvenih znanosti Ivo Pilar.

Svi provedeni intervjui su snimljeni i transkribirani, uz usmeni informirani pristanak sudionika. Transkripti i snimke su pročitani i preslušani više puta kako bi se osigurala upoznatost svih članova tima s prikupljenim istraživačkim materijalima. Time je također osigurano to da se ne promijeni značenje/da ne dođe do pogrešnog shvaćanja onoga što su sudionici rekli tijekom intervjua. Analiza je bila tematska i induktivna, bazirana na načelima utemeljene teorije (Glaser i Strauss 1967.; Strauss i Corbin, 1990.). To je uključivalo čitanje transkripta intervjua, bilježenje ključnih koncepata, ključne teme, obrasce, dosljednost, kontradikcije i varijacije. Ovakav pristup omogućio je da ključne teme proizađu iz prikupljenih informacija, umjesto da bude nametnut »pristup odozgo prema dolje«, pri čemu su teme unaprijed određene. Korištena je metoda otvorenog kodiranja kako bi se otkrilo razumijevanje, značajke i koncepti usluga za beskućnike, koje su sudionici identificirali kao važne i značajne.

${ }^{3}$ U Hrvatskoj postoji 14 prihvatilišta i prenoćišta za beskućnike. U izvješću Pučke pravobraniteljice (2020.) navodi se da su u 2019. centri za socijalnu skrb (CZSS) evidentirali 584 beskućnika, 478 muškaraca i 106 žena, dok je ukupni kapacitet prihvatilišta/prenoćišta bio namijenjen za 383 beskućnika. Međutim, ovisno o definiciji beskućništva, Hrvatska mreža za beskućnike procjenjuje da je u Hrvatskoj između 1000 i 10000 beskućnika. 
U ovom članku, razmotrit ćemo neke od ključnih koncepata i tema koje proizlaze iz našeg istraživačkog rada u području kvalitete i regulacije usluga za beskućnike u Hrvatskoj.

\section{REZULTATI: STANJE U HRVATSKOJ}

\section{Pravni dokumenti koji reguliraju kvalitetu usluga za beskućnike}

Nedostatak formalnih standarda kojima bi se regulirala kvaliteta socijalnih usluga diljem Europe Allen (2012.: 160) pripisuje činjenici da su ove usluge u europskom kontekstu tradicionalno doživljavane i organizirane kao »javne«, te »asimetriji « prisutnoj između pružatelja i korisnika takvih usluga. Drugim riječima, korisnici ovih usluga su »presiromašni da bi usluge plaćali iz svog džepa ili suviše nemoćni da bi se aktivno uključili u odabir pružatelja usluga « (ibid), odnosno u hrvatskom kontekstu mogućnost izbora često uopće nemaju. Wolf i Edgar (2007.: 18) ističu dokument koji je na razini Europske unije odigrao važnu ulogu u pravnom reguliranju socijalnih usluga među zemljama članicama. Europska komisija je 2006. godine izdala Komunikaciju o socijalnim uslugama od općeg interesa u kojoj je navedeno da, striktno govoreći, socijalne usluge ne spadaju pod javnu upravu, ali da javne politike i javno financiranje ima glavnu ulogu u pružanju socijalnih usluga (ibid.). Prema FEANTSA-inom izvješću (2011.: 9), s obzirom na javno financiranje i povećanje broja javnih natječaja za dodjelu financijskih sredstava pružateljima socijalnih usluga, to je značilo i uvođenje načina financiranja koji je manje održiv jer zahtijeva brojčano mjerljive ishode i uvođenje metodologije mjerenja ishoda. Budući da je Hrvatska tada bila u pretpristupnoj fazi za ulazak u EU, a 2013. je postala članicom, to se odrazilo i na pravnu regulaciju socijalnih usluga (uključujući i usluge za beskućnike) u Hrvatskoj. Tako je kvaliteta usluga za beskućnike na nacio- nalnoj razini regulirana dvama pravilnicima - Pravilnikom o minimalnim uvjetima za pružanje socijalnih usluga (NN, 40/2014.) i Pravilnikom o standardima kvalitete socijalnih usluga u djelatnosti socijalne skrbi (NN, u143/2014.).

Pravilnik o minimalnim uvjetima za pružanje socijalnih usluga propisuje minimalne uvjete koji se odnose na prostor i opremu kojom pružatelji socijalnih usluga raspolažu, sadržaj i opseg usluga, kao i minimalni broj radnika te trajanje i strukturu stručnog rada s korisnicima. Prvi dio Pravilnika odnosi se na sve pružatelje socijalnih usluga, a drugi dio definira uvjete za pružatelje usluga za specifične skupine korisnika, pri čemu se pojedini uvjeti propisani u drugom dijelu razlikuju od onih iz prvog dijela (npr. u općem dijelu stoji kako su kreveti na kat zabranjeni, a u posebnom dijelu za beskućnike stoji da su dopušteni itd.). Prema Zakonu o socijalnoj skrbi (čl. 184, st. 2), ispunjavanje minimalnih uvjeta za pružanje socijalnih usluga ispituje povjerenstvo koje, u slučaju usluga za beskućnike, imenuje jedinica lokalne (regionalne) samouprave, odnosno Grad Zagreb. Ispunjavanje minimalnih uvjeta propisanih ovim Pravilnikom uvjet je za dodjelu licence (čl. 253), a ukoliko se očevidom utvrdi da pružatelj usluge ne ispunjava neki od uvjeta, povjerenstvo propisuje rok do kojeg je potrebno ukloniti nedostatke (čl. 251). Tako je, primjerice, jednom od prenoćišta naloženo da visinu ograde na balkonu podigne za 10 centimetara, kako bi dostignula propisani minimum. Iako je Pravilnik na snagu stupio 2014. godine, još uvijek postoje prihvatilišta i prenoćišta koja rade bez posjedovanja licence.

Pravilnik o standardima kvalitete socijalnih usluga u djelatnosti socijalne skrbi (NN, 143/2014.) je dokument koji propisuje razinu koju socijalne usluge moraju doseći kako bi se mogla mjeriti postignuća. Svrha standarda je omogućiti da se na pouzdaniji 
način ocijeni kvaliteta pružene usluge. U Pravilniku se navodi da su standardi:

- univerzalni - primjenjivi na sve tipove $\mathrm{i}$ sve pružatelje socijalnih usluga, bez obzira na to radi li se o državnoj ustanovi, privatnoj, komercijalnoj ili neprofitnoj organizaciji koja pruža socijalne usluge

- osmišljeni na takav način da pružatelji socijalnih usluga temeljem zadanih pokazatelja sami definiraju važne kriterije u svojoj dokumentaciji (npr. ciljeve usluga, misiju, ciljane skupine korisnika, kapacitet, procedure, načine na kojima se osigurava poštovanje prava korisnika, načela pružanja usluga i druga interna pravila). Podijeljeni su u 17 općih standarda: 1. dostupnost informacija, 2. dostupnost usluga, 3. povezivanje i suradnja 4. procjena i planiranje, 5. prijem i otpust, 6. odlučivanje i samoodređenje, 7. privatnost i povjerljivost, 8. sigurnost od izrabljivanja, 9. restriktivni postupci, 10. prigovori i žalbe, 11. rukovođenje, 12. upravljanje, 13. zaposlenici, 14. rad volontera, studenata na praksi i pripravnika, 15. pristupačnost okoliša, 16. uvjeti prilagođeni korisnicima i 17. sigurnost i zaštita.

Međutim, iz intervjua provedenih u sklopu istraživanja, proizašla je informacija da neki od pružatelja usluga za beskućnike imaju uvedene standarde kvalitete, dok ih drugi još nisu uveli te da postoji problem s primjenom Pravilnika u praksi. Kako su autorice saznale od jednog od intervjuiranih stručnjaka:

»To je jedna papirologija, ja se slažem da oni trebaju postojati, međutim pitanje je njihove provedbe. Sve vam zahtijeva ljude (...) Znači, standardi su nula ako nema tko provodit.« (KI_02)

Problem provedbe standarda kvalitete u praksi, potvrdili su i drugi sugovornici:

»Teško je, nastali smo tako kako jesmo, kako je rekao, na vjetrometini sa mon- tažnim objektima koji danas ne zadovoljavaju standardima kojima trebaju, niti visinom niti prostorom. I onda da, analiziramo se, sami sebe svaki dan ocjenjujemo što bi trebalo biti papirološki potkrijepljeno, ali jednostavno nemamo mogućnosti da mi utječemo sad, to je sad viša sila.«(KI_04)

No, neusklađenost propisa i njihove praktične provedbe u slučaju osiguravanja kvalitete usluga za beskućnike nije jedinstvena za Hrvatsku. FEANTSA (2011.: 17) izvještava da je u Češkoj izostalo pravovaljano uvođenje općih standarda, a njihova primjena se ne nadzire, dok su neprofitne organizacije koje rade s beskućnicima istaknule da imaju poteškoće u ostvarivanju svih zahtijevanih kriterija jer to iziskuje sustavnu organizacijsku promjenu, bez adekvatne potpore. Sukladno tome, i informacijama navedenim na početku ovog poglavlja, pravnu regulaciju usluga za beskućnike i njene posljedice, osim u nacionalnom kontekstu, treba promatrati i u europskom, ali to je rasprava koja ostaje otvorena za buduće radove, dok će ovaj i dalje ostati fokusiran na nacionalnu razinu.

\section{Dostupnost usluga za beskućnike}

Dok prihvatilišta pružaju uslugu cjelodnevnog boravka i prehrane, prenoćišta osiguravaju noćenje, uz jedan obrok. Iz tog razloga, korisnici prihvatilišta gube pravo na zajamčenu minimalnu naknadu (iako su mnogi stručnjaci kritični prema ovoj praksi jer korisnike socijalnih usluga stavlja u nejednak položaj), a korisnici prenoćišta isto pravo zadržavaju.

Prema Zakonu o socijalnoj skrbi (NN, 157/2013.), veliki gradovi i gradovi sjedišta županija dužni su u svom proračunu osigurati sredstva za uslugu prehrane u pučkim kuhinjama, kao i pružanje usluga smještaja u prihvatilištima ili prenoćištima za beskućnike. Ipak, postoji 10 županija u kojima ne postoje prihvatilišta ili prenoćišta 
za beskućnike. To su: Međimurska, Krapinsko-zagorska, Virovitičko-podravska, Vukovarsko-srijemska, Brodsko-posavska, Sisačko-moslavačka, Koprivničko-križevačka, Ličko-senjska, Bjelovarsko-bilogorska i Požeško-slavonska. Prema informacijama dobivenim u intervjuu s predstavnicama MDOMSP-a, Ministarstvo je u komunikaciji sa županijama koje nemaju otvorena prihvatilišta ili prenoćišta za beskućnike. Kao što navode:

»Evo samo da napomenemo da smo napravili evidenciju koje županije nemaju prihvatilišta, odnosno prenoćišta, imamo 10 takovih županija i to se uvijek nastoji nekako sa županima vidjeti koji su to razlozi, njihovi su najčešći odgovori da nemaju na svojem području beskućnika ili ih nemaju u većem broju.« (KI_13)

No, dosad nijedna jedinica lokalne/regionalne samouprave nije sankcionirana zbog toga što nije osigurala uslugu prenoćišta/prihvatilišta. Kako su objasnili u MDOMSP-u:

»Pa u Zakonu o socijalnoj skrbi baš i nema kaznenih odredbi, ali sam pojam ‘socijalna skrb' obvezuje jednako državnu kao i lokalnu i regionalnu razinu, pa se uvijek ide na to da će biti prepoznat problem, da će se problem rješavati najbolje kako se bude mogao rješavati. Nije se još dogodilo da se u nekoj županiji pojavio neki beskućnik, a oni nemaju sklonište i da je čovjek ostao na cesti. Takvih informacija nismo dobivali u odjelu koji je zadužen za beskućnike u zadnje tri godine od kad sam u njemu.« (KI_14)

S druge strane, iskustva i saznanja djelatnika zaposlenih u prihvatilištima i prenoćištima govore suprotno. Ističe se primjer jednog od gradova u kojem usluga prihvatilišta/prenoćišta ne postoji:
»Mi smo pokušali pravnim putem prema tom gradu, prozivali smo ih kroz medije, oni su rekli: 'Mi trenutno u proračunu nemamo mogućnosti otvaranja.', a mi znamo da u tom gradu ima 10 beskućnika koji spavaju na ulici, a nema kazne.«( KI_01) nici:

Taj problem uočili su i drugi sugovor-

»Ja zaista ne znam, ja sam, evo, sretna kad čujem da se bilo gdje otvori novo prihvatilište ili prenoćište jer znam da zaista treba, da nam ljudi dolaze iz cijele Hrvatske jer u njihovim mjestima nema.«(KI_09)

\section{Načini financiranja postojećih usluga}

Mjere Europske unije kojima je cilj deregulacija tržišta, kako naglašava Allen (2012.: 159), odnose se i na deregulaciju usluga, čime se želi potaknuti produktivnost i kompeticija među pružateljima usluga, povećati mogućnost izbora njihovih korisnika i time smanjenje cijena. Ipak, kada se govori o socijalnim uslugama, uvođenje ovakvog principa naišlo je na mnogo kritika zbog negativnog utjecaja koji bi imao na socijalnu jednakost i solidarnost, a i na samu kvalitetu usluga koja bi se smanjivala kako bi pružatelji pokušavali smanjiti troškove (Allen, 2012.; Héritier, 2001.).

Prema istraživanju EOH 2018. u koje je bilo uključeno 16 zemalja članica EU-a (Hrvatska nije sudjelovala), većina pružatelja usluga za beskućnike pripada neprofitnim organizacijama, dok lokalne vlasti rjeđe igraju direktnu ulogu u pružanju usluga za beskućnike (Pleace, Baptista, Benjaminsen, i Busch-Geertsema, EOH 2019.: 8). Ponovno se situacija preslikava na Hrvatsku pa su tako $\mathrm{svi}^{4}$ sudionici intervjua ujedno predstavnici udruga, ne-

\footnotetext{
${ }^{4}$ Osim predstavnika Ministarstva za demografiju, obitelj, mlade i socijalnu politiku.
} 
profitnih ili vjerskih organizacija koji su u svome mjestu pokrenule uslugu prenoćišta ili prihvatilišta te imaju ugovore s jedinicama lokalne (regionalne) samouprave o financiranju navedenih usluga. Također, kod pružatelja usluga prenoćišta čest je slučaj da kroz druge projekte osiguravaju sredstva za rad dnevnih centara, kako korisnici prenoćišta preko dana ne bi morali na ulicu te kako bi im se ponudila prilika za sudjelovanje u različitim strukturiranim i organiziranim aktivnostima, mogućnost razgovora sa stručnim osobljem, korištenje računala i slično.

Činjenica je da se raspoloživost financijskih resursa razlikuje u različitim jedinicama lokalne (regionalne) samouprave. Usporedbe radi, prema podacima Ministarstva regionalnog razvoja, ${ }^{5}$ na listi indeksa razvijenosti jedinica regionalne samouprave, Grad Zagreb je na prvom mjestu s indeksom 117,758, što ga svrstava u 4. razvojnu skupinu, dok indeks za Karlovačku županiju iznosi 95,191 te je svrstana u 2. razvojnu skupinu. Sukladno tome, problem financiranja postojećih usluga za beskućnike pokazao se temeljnim problemom koji utječe na kvalitetu usluga za beskućnike. Načelno, jedinice lokalne/regionalne samouprave financiraju »osnovni pogon $\ll$ :

»Oni financiraju ono što je najosnovnije: obroci, djelatnici, zgrada, režije, a sve ove dodatne aktivnosti i stvari financiramo projektno ili programski.« (KI_06)

Međutim, iznosi koji su jedinice lokalne (regionalne) samouprave u mogućnosti izdvojiti za financiranje usluga prihvatilišta/ prenoćišta često nisu dostatni da se pokriju svi troškovi za rad prenoćišta/prihvatilišta (režijski troškovi, troškovi prehrane i higijenskih potrepština za korisnike, troškovi zaposlenog osoblja itd.). Primjerice, za jedno od prenoćišta grad izdvaja 220000 kuna. Ta sredstva nisu dostatna da zaposle tri djelatnika na noćnim dežurstvima, iako bi prema Pravilniku o minimalnim uvjetima za pružanje socijalnih usluga trebali, pa su u trenutku provedbe intervjua (lipanj 2019.) zapošljavali dva. Za drugo prenoćište grad izdvaja 136000 kuna godišnje, dok su njihovi ukupni godišnji troškovi 580 000 kn. Razliku u potrebnim sredstvima osiguravaju kroz druge projekte, ovisno o dostupnim natječajima.

Prihvatilišta koja vode organizacije poput Crvenog križa ili Caritasa, u manjoj se mjeri, u odnosu na druge pružatelje usluga za beskućnike, susreću s problemom financiranja, budući da ne raspolažu većim financijskim, ali i drugim resursima (ljudski resursi, donacije i sl.). No, bez obzira na to, činjenica je da sve organizacije koje su pružatelji usluga za beskućnike, ovise o projektima i dostupnosti financijskih sredstava putem različitih natječaja za projekte. Upravo taj problem istaknula je većina sugovornika u intervjuima, budući da su svima u periodu provedbe intervjua u tijeku bili trogodišnji projekti financirani od strane MDOMSP-a. Kao što je ranije navedeno, neki od pružatelja usluga, kroz trogodišnji projekt su omogućili uslugu dnevnog boravka za beskućnike, neki su kroz projekte osigurali stambene zajednice za mlade beskućnike i za žene beskućnice, neki različite psiho-socijalne, radno-okupacijske i kreativne aktivnosti za korisnike. Tako je $\mathrm{u}$ jednom intervjuu istaknuto:

»Projekt je do kraja 10. mjeseca, nakon toga... I sad znači, projekt istekne, ne bude ni dnevnog boravka, što će raditi preko dana.«(KI_05)

Iako je provedba tih projekata završila 31. listopada 2019., novi natječaj raspisan je tek 29. studenog 2019. Ako se u obzir uzme trajanje natječaja od mjesec dana, proces ocjenjivanja pristiglih projektnih prijedloga

\footnotetext{
${ }^{5}$ Dostupno na: https://tinyurl.com/tmx7wdf.
} 
i konačno potpisivanje ugovora, jasno je da u pružanju ovih usluga nema kontinuiteta. U međuvremenu, zbog nedostatka financijskih sredstava ukinuti su dnevni boravci za beskućnike (što znači da su korisnici prenoćišta primorani dane provoditi na otvorenom), zatvorene su stambene zajednice čiji su korisnici vraćeni u prihvatilište te su prekinute različite aktivnosti socijalne inkluzije.

No, kako je već navedeno, unatoč opisanom diskontinuitetu, projektno financiranje u financijskom smislu predstavlja jedinu mogućnost da pružatelji usluga za beskućnike svojim korisnicima pruže više od onog »osnovnog « (smještaj, hrana, higijena i usredotoče se na različite aktivnosti koje će uistinu omogućiti njihovu socijalnu inkluziju. Također, održivost takvog načina financiranja je upitna:

»Mislim da, spustiti samo na lokalnu zajednicu i tipa taj problem oko projekata, di sad opet vraćaju na jednogodišnje i tako, kontinuirana neka borba da se vidi kolika je potreba.«(KI_06)

Uz sve navedeno, nameće se i pitanje kompetencija organizacija za pisanje projekata pa je tako jedan od sudionika zaključio:

» (...) beskućnici u ponekim gradovima ovise o sposobnosti organizacije koja pruža uslugu, to se ne smije događat, ne može beskućnik u (...) bolje zato što je tu udruga (...) jer to jednostavno ne smije bit, a beskućnik u, ne znam, u nekom drugom gradu, neka druga organizacija ima malo lošije pa piše projektne prijedloge pa da, pa da im usluga bude lošija zbog pisanja projekata, znači standard u pružanju, standard da se provede u financiranju, da svi dobivaju jednaki iznos i da se usluga jednostavno standar- dizira da bude jednostavno ista usluga $u$ Zagrebu, u Splitu u (...)« (KI_01)

\section{Kvaliteta smještajnih objekata}

Prihvatilišta i prenoćišta koja su obuhvaćena ovim istraživanjem uglavnom zadovoljavaju tehničke propise određene Pravilnikom o minimalnim uvjetima za pružanje socijalnih usluga, no kako su neki od sudionika sami istaknuli, to je rezultat toga što su predstavnici prihvatilišta i prenoćišta imali priliku sudjelovati u sastavljanju Pravilnika. Tako sva spomenuta prihvatilišta i prenoćišta koja primaju osobe oba spola osiguravaju odvojene spavaonice te sanitarne čvorove za muškarce i žene. Broj osoba koje dijele spavaonice kreće se od dvije do pet, a u jednome prenoćištu spavaonicu dijeli 16 korisnika. ${ }^{6} \mathrm{Na}$ jedan sanitarni čvor, odnosno wc i tuš dolazi od 4 do 7 korisnika, iako ih u nekim slučajevima koriste i osobe u potrebi koje nisu korisnici (npr. osobe koje Žive na ulici ili drugim neadekvatnim uvjetima). Valja naglasiti kako su se u trenutku provođenja istraživanja među obuhvaćenim ustanovama našla dva prihvatilišta koja rade usprkos činjenici da ne zadovoljavaju uvjete potrebne za dobivanje licence - no, ovdje se radi o neriješenim imovinsko-pravnim odnosima, a ne o samoj kvaliteti opreme. U Hrvatskoj postoji i prenoćište koje posjeduje licencu usprkos tome što ne zadovoljava sve uvjete propisane Pravilnikom, točnije visinu stropa u smještajnim objektima. No, valja razlikovati »zadovoljavanje propisanih minimalnih uvjeta« od »pružanja kvalitetne usluge«. Iako su minimalni uvjeti, kako je opisano, uglavnom zadovoljeni, kvaliteta smještaja koje smo u sklopu ovoga istraživanja obišle poprilično varira, kako u smislu samih objekata u kojima se pružaju usluge, tako i u smislu opremljenosti i uređenosti prostorija.

\footnotetext{
${ }^{6}$ Pleace i sur. (2020:: 7) ističu da zemlje sjeverozapadne Europe s relativno visokim BDP-om ulažu više financijskih sredstava u usluge za beskućnike pa su pojedinačne sobe u prihvatilištima i prenoćištima uobičajena praksa u tim zemljama.
} 


\section{KVALITETA SOCIJALNIH USLUGA}

\section{Problem nedovoljnog broja djelatnika}

Prema Pravilniku o minimalnim uvjetima za pružanje socijalnih usluga, prihvatilišta koja mogu primiti do 150 korisnika dužna su zapošljavati dva socijalna radnika, jednog stručnjaka zaduženog za inkluziju i psihosocijalnu pomoć te jednog zdravstvenog djelatnika. Prenoćišta s jednakim smještajnim kapacitetom moraju osigurati jednog socijalnog radnika na puno radno vrijeme te stručnjaka zaduženog za inkluziju i psihosocijalnu pomoć na pola radnog vremena. No, ponovno, valja ukazati na razliku između propisanih minimalnih uvjeta i broja stručnog osoblja potrebnog za kvalitetno pružanje usluga psihosocijalne podrške i reintegracije u društvo. Tako su u jednom od uključenih prihvatilišta istaknuli:

» (...) mi se ponekad osjećamo k’o vatrogasci, samo možeš ugasit neki požar. Ja ne mogu, recimo, nekom reć: 'Ti ćeš mi svaku srijedu u 15:00 dolazit. Tak ćemo se dogovorit.', jer tu neku sljedeću srijedu u 15:00 mogu čekat tu hitnu za nekoga tko ima ono, nekakvo akutno psihotično stanje i opasan je za sebe i okolinu.«(KI_08)

Djelatnici manjih prihvatilišta i prenoćišta s druge su strane isticali kako imaju kapaciteta kvalitetno se posvetiti svakom korisniku, no bitno je naglasiti kako su stručni djelatnici u nekim prenoćištima zaposleni projektno, a time i kratkoročno, što ponekad dovodi do toga da je ustanovama teško djelatnike zadržati i do kraja trajanja ugovora, budući da svi preferiraju dugotrajnije mogućnosti zaposlenja. To potvrđuje i sljedeći primjer:

»I šta bi ona sad, razgovaramo često, što bi htjela napravit i započet, a misli si - ja i tako odoh, neće me ostavit u gužvi da mi ne natovari svašta. Ja se malo zezam, ali je tako. A kad bi žena znala da je gazdarica tu, da cee tu bit i za 5 godina, onda bi pravila pritisak i na Grad, ova zgrada nama ne odgovara, dajte nam drugi prostor i tak dalje i tak dalje... Razumijete...«(KI_03)

Dodatni je problem to što za prenoćišta manjeg kapaciteta nije predviđen rad stručne osobe na puno radno vrijeme, što može značiti svega 8 radnih sati tjedno pa je prenoćištima teško pronaći osobu kojoj bi takvi uvjeti odgovarali. Nekim je prenoćištima/prihvatilištima teško pronaći i volontere, prvenstveno zbog lokacije udaljene od gradskog centra. Ipak, neki od naših sugovornika naveli su kako povremeno imaju volontere koji se dolaze družiti i igrati društvene igre s korisnicima, dok su drugi kroz volonterske aktivnosti uspješno uključili širu lokalnu zajednicu. Zbog nedostatka medicinskog osoblja uključenog u rad prihvatilišta/prenoćišta, neki pružatelji usluga kroz volonterski angažman liječnika i medicinskih sestara omogućuju preglede svojim korisnicima.

Iako su ranije navedeni minimalni brojevi stručnog osoblja koji prihvatilišta i prenoćišta moraju osiguravati kako bi uopće mogla pružati usluge sukladno propisima, ne osiguravaju sve županije sredstva za njihovo zapošljavanje, što pružanje psihosocijalnih usluga čini nekonzistentnim.

\section{Primjeri dobre prakse: provedba inkluzivnih aktivnosti}

Kao pozitivan primjer u ovome kontekstu pokazala se praksa prihvatilišta, u kojem troje djelatnika radi s 11 korisnika. Izrazito im je važno da se korisnici ovdje zadržavaju što kraće, pa prosjek boravka u prihvatilištu trenutno iznosi malo preko godine dana. Unutar godinu dana do trenutka provođenja ovog istraživanja, na kapacitet od 11 ovdje se izmijenilo 25 korisnika, a prosjek duljine boravka podižu oni kojima dozvole produljenje boravka iz »posebnih 
okolnosti« (primjerice, dok osoba ne otplati kredit koji sprječava njen financijski oporavak ili dok mlada osoba ne završi školovanje). Recidivi (povratak korisnika) su u ovom prihvatilištu izrazito rijetki, čemu doprinosi dnevni centar koji im omogućuje nastavak regularnog kontakta s bivšim korisnicima prihvatilišta, zbog čega u slučaju potrebe mogu na vrijeme reagirati i poduzeti korake potrebne za sprječavanje povratka osobe u beskućništvo. Uz troje djelatnika koji su svakodnevno prisutni u prihvatilištu, korisnicima je na raspolaganju i vanjska suradnica koja dva puta tjedno pruža individualnu i grupnu psihosocijalnu terapiju, a prihvatilište ima i vrlo razvijenu mrežu suradnje s drugim institucijama i udrugama na lokalnoj razini. U istom prihvatilištu veliku važnost pridaju radno-okupacijskim aktivnostima, pa osim održavanja prostorija te okućnice, korisnici sudjeluju i u nizu radionica. Radove proizvedene u kreativnoj radionici redovito sami prodaju na lokalnim sajmovima, tijekom kulinarskih radionica uče kako pripremiti zdrav i jeftin obrok, a tu su i sportske i informatičke radionice, radionice financijskog opismenjavanja itd.

Ovakve se radionice, kako u spomenutom primjeru, tako i u drugim prihvatilištima, uglavnom financiraju putem programa resornog ministarstva. Uspješan primjer tako financiranih aktivnosti su i programi osposobljavanja koje nudi i drugi pružatelj usluga za beskućnike uključen u ovo istraživanje. Programi uključuju osposobljavanje za njegovateljice, sobarice, pomoćne kuhare, pomoćne konobare, proizvođače voća i povrća, ratare, suhu gradnju, te osposobljavanje za trimer, kosilicu i motornu pilu, čime se stječu kompetencije koje su najtraženije na tržištu sezonskih poslova i javnih radova. Isto prenoćište putem javnih radova korisnike zapošljava na održavanju prostorija i obrađivanju zemlje, a uz pomoć gradske institucionalne podrške korisnici se po rotirajućem principu zapošljavaju i na poslovima dnevnog dežurstva.
Treći primjer dobre prakse koji se istaknuo kroz ovo istraživanje je prenoćište koje je ostvarilo izuzetno kvalitetnu komunikaciju s cijelom lokalnom zajednicom pa se u dugogodišnje volonterske akcije u prenoćištu, podizanje javne svijesti o problemu beskućništva i javne akcije prikupljanja financijskih sredstava uključuju svi članovi zajednice, od djece do umirovljenika.

No, usprkos ovim pozitivnim primjerima, kako zaključujemo na temelju vlastitih opažanja te opažanjima stručnjaka koji su sudjelovali u ovome istraživanju, značajan broj prihvatilišta i prenoćišta za beskućnike u Hrvatskoj svojim korisnicima ne nudi dovoljno radno-okupacijskih aktivnosti bilo zbog nedostatka kadra, nedovoljnih sredstava ili pak neadekvatnog kadra, što utječe na kvalitetu usluga i otežava njihovu socijalnu inkluziju.

\section{Inkluzija korisnika s različitim potrebama}

Tijekom istraživanja uočile smo i kako hrvatska prihvatilišta i prenoćišta vrlo rijetko imaju razrađene programe namijenjene nekoj specifičnoj skupini korisnika, primjerice, ženama, mladima, osobama treće životne dobi, osobama s psihičkim ili intelektualnim teškoćama i sl. Na pitanja o tome kako pristupaju ovim skupinama korisnika, djelatnici prihvatilišta i prenoćišta uglavnom su naglašavali individualan pristup svakome korisniku:

» (...) imamo te aktivnosti, znači (...) imamo i te neke redovite sastanke, neke motivacije za zapošljavanje, ali ja bi rekao da se najviše tu radi individualno, procjenjujemo sposobnosti i kapacitete i vidimo za šta je ta osoba sposobna i onda probamo naći neko rješenje za nekakav posao ili nešto. Postoje ti grupni sastanci gdje ih se tako motivira, ali ja bi rekao da je taj individualni pristup bolji, jer dosta su oni svi različiti.«(KI_07) 
Iako ne postoje razrađeni programi usmjereni na neke uže definirane skupine korisnika, u socijalnoj inkluziji osoba u statusu beskućnika su se vrlo uspješnima pokazale stambena zajednica za žene beskućnice te stambena zajednica za mlade beskućnike jer takav oblik smještaja i podrške omogućuje individualizirani pristup svakom pojedinom korisniku usluge. Pozitivne je učinke proizveo i program »Job Club« koji je jedan od pružatelja usluga provodio u suradnji s Hrvatskim zavodom za zapošljavanje, a bio je namijenjen radno sposobnim korisnicima, od kojih su mnogi bili osobe mlađe životne dobi. Također, iako ne u obliku formalnog programa, djelatnici u jednom prenoćištu problemima mlađih korisnika pristupali su na način da posreduju u rješavanju njihovih konflikata sa starijim članovima obitelji, što se, prema njihovim riječima, pokazalo kao efikasna mjera.

U svim prihvatilištima i prenoćištima koja su obuhvaćena ovim istraživanjem smješteni su i bivši ovisnici o psihoaktivnim sredstvima, koji trenutno primaju supstitucijsku terapiju, a za to da ju uzimaju pravilno i redovito brinu se djelatnici. Među korisnicima svih prihvatilišta i prenoćišta koja su sudjelovala u ovome istraživanju česte su osobe narušenog psihičkog zdravlja. Iako su prijašnjih godina pomagale radno sposobnim korisnicima da pronađu zaposlenje, u vrijeme provođenja ovoga istraživanja osoblje $u$ jednom prihvatilištu istaknulo je kako nemaju takvih korisnika, naglasivši prisutnost »teško psihički bolesnih« osoba. »Promjenu strukture« korisnika prihvatilišta naglasio je jedan od sudionika istraživanja:

» (...) prihvatilišta su se pretvorila $u$ domove za psihički bolesne, osobe s intelektualnim teškoćama - evo jučer gledam u (...), osoba s invaliditetom u kolicima, jedna osoba teško hoda, osobe starije od 65 godina, ne da ima 65, nego 87 najstariji, i tako dalje. To su osobe koje ne bi trebale biti u prihvatilištu, nego u odgovarajućoj instituciji socijalne skrbi.«(KI_02)

Radi se o osobama, smatra naš sugovornik, koje nije moguće rehabilitirati u periodu od 6 mjeseci do godine dana, a njihovo prisustvo u prihvatilištu usporava i proces reintegracije zdravih korisnika. I u drugim su prihvatilištima naglasili ovu problematiku:

»Bilo je teških situacija, baš teških. (...) mislim... tamo je pet ljudi u sobi. Oni (Centar za socijalnu skrb) pošalju čovjeka koji... mislim koji je lud, ovi se tamo boje da cee ih ubit...« (KI_07)

Trend povećanje udjela psihički oboljelih među osobama u statusu beskućnika zapažen je u mnogim državama tijekom 1960-ih i 1970-ih godina i to uslijed procesa deinstitucionalizacije usluga skrbi za mentalno zdravlje (UN, 2014.: 22). Resorno ministarstvo u Hrvatskoj početkom ovoga desetljeća započelo je s planovima deinstitucionalizacije i transformacije usluga socijalne skrbi ${ }^{7}$, a prema riječima djelatnika prihvatilišta i prenoćišta uključenih u ovo istraživanje, centri za socijalnu skrb upućuju im ovakve korisnike zbog nedostatka adekvatnijih smještaja.

Iako su djelatnici svih prihvatilišta i prenoćišta naglasili kako su u redovnom kontaktu s psihijatrima svojih korisnika i kako vode računa o tome da korisnici redovito $i$ pravilno uzimaju propisanu terapiju, kao možda najefikasnije rješenje ističe se praksa jednog prihvatilišta, čiji korisnici narušenog psihičkog zdravlja borave u dnevnoj bolnici

${ }^{7}$ 2010. godine izdan je Plan deinstitucionalizacije i transformacije domova socijalne skrbi i drugih pravnih osoba koje obavljaju djelatnost socijalne skrbi u Republici Hrvatskoj 2011.-2016. (2018.), a trenutno je na snazi Plan deinstitucionalizacije, transformacije te prevencije institucionalizacije: 2018.-2020. godina (izdan 2018.).uuuu 
Odjela za psihijatriju u lokalnoj bolnici, a u prihvatilište dolaze na noćenje. Usprkos tome što prihvatilišta načelno prihvaćaju radno sposobne osobe koje su se u statusu beskućnika našle privremeno spletom okolnosti, osim psihički oboljelih, ovdje se često upućuju i druge skupine s kompleksnim potrebama:

»Jedan je bio slomio kuk, pa je išao na operaciju, pa se vratio, pa se razbolio, dobio karcinom... on je nama tu praktički umirao. Mi smo imali užasno velike probleme, da mi tu osobu nismo mogli smjestiti niti u bolnicu, niti u nekakav dom, i to je bilo stvarno jako teško jer on je postao inkontinentan... Njegova liječnica je osigurala patronažnu sestru da dođe tri puta tjedno po sat vremena, mislim njemu treba 24-satna skrb, on je u peleni u krevetu.«(KI_07)

\section{Izazovi i ograničenja}

Uz veliku količinu administrativnih zaduženja, ograničene izvore prihoda i ovisnost o projektnom financiranju, nedovoljan broj djelatnika te ulaganje njihovog vremena i energije u ispunjavanje potreba korisnika koji ne bi niti trebali biti smješteni u prihvatilištu ili prenoćištu, već u drugim institucijama socijalne skrbi, prihvatilištima i prenoćištima ostaju vrlo mali kapaciteti za kvalitetan rad na psihosocijalnoj rehabilitaciji i društvenoj inkluziji zdravih i radno sposobnih korisnika, koji bi imali potencijala započeti samostalan život unutar zakonski propisanog roka. No, usprkos svim navedenim poteškoćama i generalnom nedostatku sustavnih programa namijenjenih određenim skupinama korisnika, iz većine intervjua s djelatnicima prihvatilišta i prenoćišta uključenih u ovo istraživanje, može se iščitati visok stupanj posvećenosti i motiviranosti djelatnika koji daju sve od sebe da unutar danih okolnosti svim korisnicima pruže što kvalitetniju potporu.

\section{Kontrola kvalitete usluga}

Pri evaluaciji usluga za beskućnike, ključno je razumjeti cilj koji si je postavio određeni pružatelj usluge. Kako objašnjava Allen (2012.: 161), važno je razlikovati pristupa li pružatelj usluga beskućništvu na način da ga prihvaća kao »stanje osobe «ili na način da želi osobi pružiti podršku pri promjeni toga stanja. Kvaliteta bi se tada mogla ocijeniti zadovoljavajućom ukoliko pružene usluge dovode do zacrtanog cilja - brzog »oporavka« iz stanja beskućništva ili pak ugodnog i dostojanstvenog života $u$ instituciji. S obzirom na zakonski dozvoljen rok boravka u prihvatilištu/prenoćištu za beskućnike od šest mjeseci do godine dana, zakonodavna razina u Hrvatskoj kao cilj usluga za beskućnike vidi reintegraciju korisnika u društvo. Posjetivši većinu prihvatilišta i prenoćišta za beskućnike, uočile smo da ovo viđenje dijeli i većina pružatelja usluga, iako ima i onih koji veći naglasak stavljaju na uređenje samog smještajnog objekta, kao i onih koji su svjesni toga da će se brojni korisnici kod njih na smještaj vratiti nakon izlaska i pokušaja samostalnog života, ali im svejedno pružaju podršku. S druge strane, usprkos zakonski propisanom roku, centri za socijalnu skrb kao državna tijela u prihvatilišta/prenoćišta upućuju osobe za koje je izvjesno da se u zadanom roku neće moći reintegrirati (često i usprkos protesta samih prihvatilišta/ prenoćišta). Može se reći da time država od prihvatilišta i prenoćišta zahtijeva pružanje usluga koje nisu sukladne cilju koji im je zakonski postavljen.

No, formalne evaluacije kvalitete $u$ Hrvatskoj ovu točku ne uzimaju u obzir, a sama kvaliteta rijetko je uopće tema evaluacija pruženih usluga.

\section{Vanjska kontrola kvalitete usluga}

Kako je navedeno ranije, radi utvrđivanja postojanja minimalnih uvjeta za pružanje socijalnih usluga prema relevantnom 
Pravilniku, jedinica lokalne/regionalne samouprave određuje povjerenstvo, čiji nadzor, u slučaju pozitivne procjene, rezultira dodjelom licence za rad. Iz razgovora sa stručnjacima i djelatnicima prenoćišta i prihvatilišta diljem Hrvatske saznale smo kako se, jednom kada se dodijeli licenca, inspekcijski nadzori kojima bi se ponovno utvrđivalo zadovoljava li ustanova i dalje sve uvjete propisane Pravilnikom više ne provode.

Voditelji svih prenoćišta i prihvatilišta obuhvaćenih ovim istraživanjem rekli su kako su dužni izvješća o radu redovito slati davateljima financijskih sredstava, a isti povremeno provode i kontrole »na licu mjesta«. Ipak, ta se izvješća i kontrole odnose na administrativne i financijske aspekte rada prenoćišta i prihvatilišta, a ne na samu kvalitetu pruženih usluga.

\section{Interna kontrola kvalitete usluga}

Wolf i Edgar (2007.: 25) »zadovoljstvo korisnika« definiraju prema di Tomassovoj i Wallardovoj definiciji, pri čemu taj pojam obuhvaća procjenu iskustava pojedinca povezanih s uslugom koju je primio te procjenu jesu li te usluge zadovoljile njegova očekivanja i potrebe. Iako na tu procjenu mogu utjecati različiti subjektivni i objektivni čimbenici, zadovoljstvo korisnika treba uzeti u obzir kao jedan od pokazatelja kvalitete usluga. Možemo zaključiti da sva prihvatilišta/prenoćišta koja su sudjelovala u istraživanju posvećuju pažnju zadovoljstvu korisnika, no razlikuju se načini na koji prikupljaju podatke. Tako jedno prenoćište i jedno prihvatilište jednom godišnje provodi anonimne ankete, jedno prenoćište kombinira provođenje ankete u sklopu pojedinih projekata s redovitim sastancima $s$ korisnicima, jedno prenoćište ankete provodi povremeno (kada se struktura korisnika promijeni; kada su dugo vremena isti korisnici u prihvatilištu, tada ne ponavljaju ankete), jedno prihvatilište zadovoljstvo ispituje samo kroz razgovore stručnih djelatnika s korisnicima, dok jedno uz razgovore ima i sandučić za žalbe u koji korisnici u slučaju nezadovoljstva mogu ubaciti anonimnu žalbu.

Više stručnih djelatnika koji rade u prihvatilištima je reklo da su korisnici uglavnom zadovoljni pruženim uslugama.

»Znači, postoji test, ono anonimno, tako da mogu oni ocijeniti naš rad, koliko su zadovoljni smještajem i tako dalje. I s radom zaposlenika. I imamo dosta dobre ocjene, negdje vrlo dobar pa do odličan.«(KI_10)

Nekoliko djelatnika je istaknulo da korisnici koji u prihvatilištu/prenoćištu borave kraći period nerijetko pokazuju veći stupanj zadovoljstva uslugama od onih koji ovdje borave godinama. To je u skladu s podacima iz kvantitativnog istraživanja iz 2015. godine $u$ kojem je sudjelovalo 14 prihvatilišta/prenoćišta, dva dnevna centra i jedna stambena zajednica, odnosno 266 osoba s iskustvom beskućništva (Družić Ljubotina, Kletečki Radović, Ogresta, 2016.: 50). Prema istom istraživanju, trećina ispitanika smatrala je da nisu potrebna poboljšanja te da su izrazito zadovoljni svim uslugama (ibid: 51), dok je manji postotak smatrao da su potrebna poboljšanja po pitanju hrane $(7,1 \%)$, čistoće $(6 \%)$ i veće slobode kretanja $(5,2 \%)$.

Po pitanju metoda (samo)procjene rada prenoćišta/prihvatilišta, odgovori djelatnika upućuju na to da kroz razgovore i sastanke s kolegama dogovaraju koji elementi rada funkcioniraju, a na kojima bi trebalo dodatno poraditi te da prilikom izrade godišnjih planova rada, trogodišnjih ili petogodišnjih planova te financijskih planova, ujedno evaluiraju svoj rad:

» (...) radimo našu internu evaluaciju i radimo, svake godine se radi operativni plan za tu kalendarsku godinu i normalno izrađujemo petogodišnje $(. .$.$) «$ (KI_01) 
Povezanost prihvatilišta i prenoćišta koja su sudjelovala u istraživanju kroz Hrvatsku mrežu za beskućnike omogućuje im međusobnu podršku i razmjenu iskustava te je postojala ideja da se uvede unificirani način evaluacije usluga i zadovoljstva korisnika. Ipak, to dosad nije realizirano, već svaka organizacija evaluaciju provodi na vlastiti način.

\section{ZAKLJUČAK}

Pojam kvalitete usluga za beskućnike teško je definirati jer među različitim pružateljima usluga postoje različiti kriteriji i prioriteti. Dok su neki usmjereniji na kvalitetu samog prostora i fizičkog okoliša u kojem korisnici prenoćišta/prihvatilišta borave, drugi veću važnost pridaju aktivnostima koje su usmjerene na psihosocijalni napredak i uključivanje radno sposobnih korisnika na tržište rada, a treći pak nastoje podjednaku pažnju posvetiti jednom i drugom kriteriju. Ipak, tu još jednom napominjemo da pitanje kvalitete prostora u kojem borave korisnici uvelike ovisi o mogućnosti prilagodbe smještajnih objekata koje su udruge/organizacije dobile na korištenje od jedinica lokalne/regionalne samouprave, a pitanje kvalitete različitih inkluzivnih aktivnosti o dostupnosti i iznosu financijskih sredstava i mogućnosti da pružatelji usluga zaposle i zadrže odgovarajući stručni kadar. Uočeno je da sva prihvatilišta i prenoćišta nemaju jednake stručne kapacitete za pisanje kvalitetnih projektnih prijava (što je složena kompetencija koju, u pravilu, djelatnici prihvatilišta/prenoćišta nisu dužni imati), a dok se god takve usluge financiraju projektno, što i radna mjesta stručnih djelatnika u prihvatilištima i prenoćištima čini nestabilnima, bit će teško ostvariti kontinuitet u kvaliteti pružanja usluga.

Iako smo kroz istraživanje ustanovile da, govoreći o različitim inkluzivnim aktivnostima, ne postoje posebni programi usmjereni na različite podskupine beskućnika (mladi, osobe treće životne dobi, žene, pripadnici etničkih manjina, osobe s kompleksnim potrebama), na nepostojanje takvih programa ne treba gledati kao na pokazatelj niske kvalitete usluge. Naime, velik broj prihvatilišta/prenoćišta ima mali smještajni kapacitet pa pojedine podskupine nisu brojnošću zastupljene i zato se individualni pristup koji su naglasili svi sugovornici čini kao logičan izbor u pristupu korisnicima.

Kada je u pitanju evaluacija usluga i mjerenje zadovoljstva korisnika, Pravilnik o standardima kvalitete socijalnih usluga trebao bi služiti kao osnova na kojoj se temelji mjerenje kvalitete. Uslijed suočavanja s drugim problemima (nedostatna financijska sredstva, nedovoljan broj djelatnika, opterećenost administrativnim poslovima koji smanjuju količinu vremena koja se može posvetiti korisnicima, korištenje objekata koje nije moguće u potpunosti prilagoditi svim potrebnim uvjetima itd.), mnoga prihvatilišta/prenoćišta nisu u mogućnosti uvesti standarde kvalitete. Umjesto toga, svako prihvatilište/prenoćište ima vlastiti sustav vrednovanja rada i zadovoljstva korisnika. Uz to, bez obzira na postojanje spomenutih pravilnika koji reguliraju kvalitetu socijalnih usluga, pitanje kvalitete čini se zanemareno od strane nadležnih drŽavnih/regionalnih/lokalnih tijela koja se ponajviše bave financijskim aspektima rada prenoćišta/prihvatilišta.

Konačno, velik dio problema proizlazi iz činjenice da su prihvatilišta i prenoćišta zakonski definirana kao pružatelji usluga čiji je cilj što brža reintegracija korisnika u društvo, dok im u praksi sama državna tijela upućuju korisnike koji zasigurno neće moći »stati na svoje noge u u roku od godine dana, odnosno korisnike koji bi trebali biti smješteni u drukčije ustanove socijalne skrbi. Time što njihova ustanova gubi jasan cilj, odnosno što im se nameću različiti ciljevi za različite korisnike (što brža reintegracija s jedne i podrška u danom stanju s druge strane), djelatnicima postaje vrlo teško adekvatno se posvetiti ijednom od tih ciljeva. Stoga bi po- 
boljšanje kvalitete usluga trebalo biti rezultat rada i suradnje niza institucija, uključujući Ministarstvo zdravstva, Ministarstvo rada i mirovinskog sustava, Ministarstvo graditeljstva i prostornoga uređenja itd.

Trenutnu ocjenu kvalitete usluga za beskućnike u Hrvatskoj u konačnici bi bilo teško svesti na kratak komentar, a kamo li na brojku. U ovome smo članku, iz perspektive djelatnika zaposlenih u sustavu pružanja usluga za beskućnike, identificirale niz problema koji postoje u sustavu koji regulira pružanje ovih usluga, ali smo isto tako istaknule posvećenost većine djelatnika prihvatilišta i prenoćišta radu s korisnicima. Ipak, za donošenje konkretnije ocjene kvalitete usluga za beskućnike u Hrvatskoj, u daljnja istraživanja svakako bi trebalo uključiti osobe u beskućništvu, koje su izravni korisnici ovih usluga.

Ovaj rad je financiran u okviru Hrvatsko-švicarskog istraživačkog programa Hrvatske zaklade za znanost i Svicarske nacionalne zaklade za znanost putem sredstava Švicarsko-Hrvatskog programa suradnje.

\section{LITERATURA}

Allen, M. (2012). Quality standards in homeless services, housing led approaches and the legacy of 'less eligibility'. European Journal of Homelessness, 6(2), 159-166. Available at https://www. feantsaresearch.org/download/ejh6_2_thinkpiece46665344423294868438.pdf

Družić Ljubotina, O., Kletečki Radović, M., \& Ogresta J. (2016). Slika podrške beskućnicima u Hrvatskoj.Zagreb: Gradski ured za socijalnu zaštitu i osobe s invaliditetom.

European Federation of National Organisations Working with the Homeless. (2011). Quality of social services from the perspective of services working with homeless people (European Report). Brussels: FEANTSA.

Glaser, B. G., \& Strauss, A. L. (1967). The discovery of grounded theory: Strategies for qualitative research. New York: Aldine.

Héritier, A. (2001). Market integration and social cohesion: The politics of public services in European regulation. Journal of Europe- an Public Policy, 8(5), 825-852. https://doi. org/10.1080/13501760110083536

Ministarstvo regionalnoga razvoja i fondova Europske unije. (2018). Vrijednosti indeksa razvijenosti i pokazatelja za izračun indeksa razvijenosti 2018. Dostupno na https://tinyurl.com/tmx7wdf

Ministarstvo za demografiju, obitelj, mlade i socijalnu politiku. (2018). Plan deinstitucionalizacije, transformacije te prevencije institucionalizacije 2018-2020. Dostupno na https://mrosp.gov.hr/ UserDocsImages/dokumenti/MDOMSP\%20 dokumenti/Plan\%202018-2020.pdf

Ministarstvo zdravstva i socijalne skrbi. (2010). Plan deinstitucionalizacije $i$ transformacije domova socijalne skrbi i drugih pravnih osoba koje obavljaju djelatnost socijalne skrbi u Republici Hrvatskoj 2011-2016. (2018.). Dostupno na http://www.uza.hr/wp-content/uploads/2017/01/ plan-deinstitucionalizacije.pdf

Pleace, N., Baptista, I., Benjaminsen, L., \& Busch-Geertsema, V. (2019). Homelessness services in Europe. Available at https://www.feantsaresearch.org/en/comparative-studies/2018/12/14/ comparative-studies-on-homelessness-number-7-2017?bcParent=763

Pleace, N., Baptista, I., Benjaminsen, L., \& Busch-Geertsema, V. (2020). The regulation and quality of homelessness services. Available at https://www.feantsaresearch.org/en/comparative-studies/2020/02/25/comparative-studies-on-homelessness-number-9-2019

Pravilnik o minimalnim uvjetima za pružanje socijalnih usluga. Narodne novine, br. 40/2014.

Pravilnik o standardima kvalitete socijalnih usluga u djelatnosti socijalne skrbi. Narodne novine, br. 143/14.

Pučki pravobranitelj. (2016, 2018, 2019, 2020). Izvješ́e pučke pravobraniteljice. Zagreb: Republika Hrvatska, Pučki pravobranitelj. Dostupno na https://www.ombudsman.hr/hr/izvjesca-puckog-pravobranitelja/

Strauss A. L., \& Corbin J. M. (1990). Basics of qualitative research: Grounded Theory procedures and techniques. Thousand Oaks, CA: Sage Publications.

United Nations. (2014). The right to adequate housing. Geneva: United Nations.

Wolf, J., \& Edgar, B. (2007). Measuring quality of services and provision in homelessness. European Journal of Homelessness, 1, 15-39. Available at https://www.feantsaresearch.org/download/ ejh_vol1_article13232276502546197893.pdf

Zakon o socijalnoj skrbi. Narodne novine, br. 157/2013, 152/2014, 99/2015, 52/2016, 16/2017, 130/2017. 


\title{
Summary
}

THE QUALITY OF HOMELESSNESS SERVICES: AN OVERVIEW OF THE CURRENT SITUATION AND CHALLENGES IN CROATIA

\author{
Lynette Šikić-Mićanović \\ Suzana Sakić \\ Stephanie Stelko
}

\author{
Institute of Social Sciences Ivo Pilar \\ Zagreb, Hrvatska
}

\begin{abstract}
Although homelessness is a multifaceted phenomenon that has aroused interest in the Croatian scientific community over the last decade, the quality of homelessness services has not been explored so far. Based on a qualitative research that included key participants in the homelessness sector, this theme is problematized through various aspects of service quality. Following an introduction and a description of the method used, this paper describes the legal regulation of quality of services for homeless people, as well as the problems that homelessness services providers encounter in practice in relation to legal documents. More specifically, this paper analyses: the availability of services for homeless people, financing models, quality of accommodation facilities, quality of social services and quality control. All these aspects of service quality are supplemented by a number of first-hand practical experiences as well as some examples of good practice.
\end{abstract}

Key words: homeless people, social services, (night) shelters, regulation, service quality. 